\title{
Working on Stories to Enhance Career Decision Making Self-Efficacy
}

\author{
K. Argyro Charokopaki ${ }^{1}$ \\ ${ }^{1}$ High School Teacher- Career Counselor (M.Sc., Ph.D), Scientific Collaborator Department of Philosophy, \\ Pedagogy and Psychology, National and Kapodestrian University of Athens, and Higher School of Educational \\ and Technological Studies, Athens, Greece. \\ Correspondence: K. Argyro Charokopaki, High School Teacher- Career Counselor (M.Sc., Ph.D), Scientific \\ Collaborator Department of Philosophy, Pedagogy and Psychology, National and Kapodestrian University of \\ Athens, and Higher School of Educational and Technological Studies, Athens, Greece. E- mail: \\ acharokop@gmail.com
}

Received: May 22, 2019

Accepted: August 21, 2019

Online Published: August 23, 2019

doi:10.5539/ijps.v11n3p63

URL: https://doi.org/10.5539/ijps.v11n3p63

\begin{abstract}
This article considers the potential complementarity of traditional career assessment and more recent narrative approaches -in particular narrative career counseling and story telling approach- to career counseling in terms of theory and practice. It describes an Integrated Qualitative Structured Interview to construct stories about the four sources of career decision making self-efficacy information: mastery experiences, vicarious learning, social persuasion and emotions regulations techniques. The model facilitates and enables narrative exploration to supplement clients' knowledge and understanding of the role of past and present influences concerning career decision making self-efficacy. The Narrative career counselling and the story telling approach and Social Cognitive Career Theory are the foundation of the qualitative structured interview based on story crafting questions.
\end{abstract}

Keywords: quantitative and qualitative career assessment, social cognitive career theory, narrative career counseling, story telling, career decision-making self-efficacy

\section{Introduction: Modern trends n Career Counselling and Career Assessment}

In the economic and social complexity of recent decades, the demand as far as career development is concerned, refers to the negotiation of the changes and the reconstruction of life and career (Peavy,1998,2000). Within this social and economic context, career choice decisions are becoming more complex because of the increasing difficulty in predicting the evolution of the occupational world (Maree, 2018).

Current complexity also influences the field of career counseling. As far as career counseling theories is concerned, one trend is the integration of the theoretical frameworks and approaches of career counseling, in order to formulate complete theoretical patterns for the interpretation of the careers (Wright \& Perrone, 2008, 2010). The most important changes refer to the construction of new - and the exploitation of older - theoretical approaches for the career development process and the career counseling methods (Amundson,2009; Guichard,2009; Savickas et al., 2009).

Theories referring to career development process which determined the counselling practice before the current post-modern era had a positivist, psychological or behaviouristic basis. The body of their conceptual constructs had as its basic underpinning the discovery of the causal relations which are thought to determine the social phenomena. Their aim was to 'discover' the career interests and skills of the individuals and the potential workers (candidate code) in order to be placed in an environment of the same or similar type so that the best possible satisfaction would be achieved for the individual as well as the employer (Nota et al., 2014). Matching people to jobs was characterised as the psychology of occupations (Hartung and Santilli, 2018) and epitomized by Holland's (1997) approach. This pattern was the first wave of career intervention and rendered dominant globally, celebrating in 2008 fifty years of application with important resonance in the scientific world until today (Nauta, 2010; Sharf, 2010). The second wave, concentrated on managing worker and other life roles over the life span in the phychology of careers, launched at mid-20 $0^{\text {th }}$ century and epitopmized by Super's (1990) life-span, life-space approach. 
Within the contemporary socioeconomic work-life context, unpredictable parameters and events get involved with the psychic, reflective processes of the individual, turning the career counselling procedure into a differentiated project each time for both parties involved (counsellor-client).

Within the contemporary socioeconomic context of life and work, unpredictable parameters and events get involved with the psychic reflective processes of the individual and the career counselling procedure becomes a differentiated project each time, for both parties involved (counsellor-client). Career counselling practitioners seek to deliver career interventions that better account for life's complexity and richness within a rearranged structure of work. Individuals must seek security in the blankets of their own life stories (Sullivan, 2011). In this way, the exclusive application of a traditional theory of career development cannot respond the counselling procedure unless it combines with some modern one, which gives emphasis on the qualitative characteristics of the client (Bujold, 2004).

The theoretical basis of new career counselling approaches came from the range of constructivism and the theory of social construction or the social constructionism. These theories refer to the structure and the formation of the human knowledge from within the action of the individual and the social intervention which constituted the forerunners of the appearance of new theoretical approaches. This happened because constructivism and social constructionism have greater capacity to accommodate the complex and dynamic processes of a rapidly changing society than theories underpinned by the logical positive worldview (McMahon, 2014). From now on, social phenomena do not have specific causative relationships and social reality is not objectively given and immutable but a 'construct' in the formulation of which human action and mutual influence contributes a great deal (McMahon, Patton, \& Watson, 2005).

The constructivist (Brown \& Brooks, 1996) and social constructivist philosophies (Brown, 2002) underpin Narrative Career Counselling, which values subjectivity, active agency, meaning making, the importance of context and the interconnection of individuals and environments. Narrative reflects the third wave of career intervention (Hartung and Santilli, 2018). This wave now focuses on making meaning through work in psychology of life design introduced at the end of the first decade of the 21 rst century and epitomized by Savickas' (2011) career construction approach.

Following the emergence of new scientific approaches in career counselling and the large movement from mechanism and focus on traits, to organicism and focus on developmental stages and then to contextualism and focus on narratives (respectively to three waves mentioned above) (Sarbin, 1986), career assessment is facing new challenges in its application. A debate aroused -considered in terms of philosophical foundations -about quantitative career assessment and narrative career counselling which place emphasis on different constructs. Thus, for some time, an uneasy relationship between quantitative career assessment and career counselling has existed (e.g. Golman, 1994; Super, 1957, in McMahon and Watson, 2012). More specifically, a critical challenge concerning the relationship between career assessment and career counselling, in particular narrative career counselling, is how this relationship may best position itself in terms of theory and practice in order to move forward in a sustainable way (McMahon \& Watson, 2012).

Moreover, a critical basic aim of the career assessment techniques today is to strengthen both self- and career-exploration of the individual (Blustein \& Flum, 1999; De Bruin \& de Bruin, 2006) as well as to support people in the decision-making process (Sampson, 2009). A new, sustainable approach appeared, drew from the strengths of both quantitative career assessment and intervention and narrative career counselling and is being used more and more to deal with career choice challenges. This trend responds to prompts for a movement with dominant test and tell metaphor evident in career assessment to that of narrative metaphor or from scores to stories in the postmodern era (Savickas, 1993). It demonstrated the value of using a combined, quantitative qualitative approach to career counselling. This potential complementarity has been adopted by many contemporary career theorists and practitioners, who have increasingly moved to an integrative approach which accords equal value and relevance to quantitative and qualitative assessment and intervention. A rapid expansion of narrative and storied approaches to career counseling is evident in the field. Maree (2014;2019), McMahon \& Watson (2012), Savickas (2011a;b), Hartung (2015), Hartung and Santilli (2018) and others have consistently stressed the importance of using creative methods and interventions to help people reflect their career-life stories (and reflect on their reflections) and overcome career-related indecision.

The present article considers the potential complementarity and describes a qualitative Integrative Structured Interview process to enhance career decision making self-efficacy, using Lent Brown and Hackett's (1994) social cognitive career theory (SCCT) and its potential complementarity with the theory of attachment (Bowlby, 1969) on the one hand, and on the other hand, narrative career counseling and story telling approach on the other 
hand. Career assessment and SCCT as far as decision making are briefly overviewed, in particular career decision making self-efficacy and sources of its information (mastery experiences, vicarious learning, social persuasion and emotions regulations techniques). Narrative career counseling, specifically the story telling approach (McMahon, 2007,2009; McMahon \& Watson 2010,2012) are also briefly overviewed because are also the basis of the structured interview process used to demonstrate the complementarity of career assessment and story telling.

\section{Literature Review}

\subsection{The Narrative Approach in Counselling and Career Counselling}

The narrative approach method, began with the psychologist J. Bruner (1986). It focuses on the personal stories of individuals and on the importance and the meanings which the individuals give to their experiences as they express themselves. These stories are considered to present coherence and consistency. The basic characteristics of this approach are: a) the dimension of the temporality in the processing and the understanding of the experiences of the individuals or the elements and specific aspects of their stories and b) the causality between the events which they narrate (Gibson, 2004; Ricoeur, 1986). In this case, counselling is considered as a 'work in progress' (Reed, 2006), a differentiated project, which makes possible the in-depth analysis and as a result the understanding of the identity of the individual. The possibility of reconstruction and remodelling of the identity exists within this process (Lapointe, 2000, in Bujold, 2004).

The narrative approach has emerged in recent decades as an important theoretical frame in the area of Career Counselling (Stebleton, 2010), stimulated to some extent by emergent needs for approaches that are responsive to more diverse clientele and more complex career issues (McMahon \& Watson,2012). Counsellors who adopt narrative theories encourage their clients to narrate their personal stories, they facilitate them to extract new meanings and to define the basic career subjects which concerns them. As a result, counsellors become facilitators of the development of educational experiences concerning their careers, and co-constructors of the produced meanings (Bujold, 2004). They play an important role in this process since they are the ones who determine and interpret, even understand the elements of the stories of their clients (Loyttyniemi, 2001, in Bujold, 2004).

Consistent with the philosophy of narrative career counselling, stories are important in the construction of identity and meaning making an important way of making sense of life experiences. Further, emphasis has been placed on the connectedness between individuals and the contextual location of their experiences and corresponding stories.

The process of establishing a career identity and specifically the mechanism of career decision-making is a central construct of the older and newer theories of career development. The narration could be used for the understanding and the promotion of the career decision-making, since the decisions are an integral element of the stories the individual narrates (Cochran, 1991).

The use of stories in the narrative approach constitutes a very valuable tool (Peavy, 1998). Consistent with other narrative approaches, the story telling uses construction of stories. The context in which the stories are constructed is also critical. The approach also has at its core the practice dimensions of the capability of the client for self-determination (agency), understanding of the experiences (meaning making) and connectedness. Two further dimensions that underline the story telling approach are reflection and learning (McMahon \& Watson, 2012). The aims of these dements are meet through the identification of knowledge, skills, abilities and values, the characteristics and emotions of the client (Campbell \& Ungar, 2004) during narrative process. Connectedness is a process that may be understood in the context of the culture and environment in which an individual's career is constructed. Reflection is a process by means of which individuals take stock of situations by examining their thoughts, feelings and responses to a situation. By meaning making, individuals make sense of their past, present and future experiences. Learning is a process of constructing and transforming experience into knowledge, skills, attitudes, values, beliefs and emotions. Agency is indicative of intentionality and individual's capacity to construct his/her career and also take action. The present article embeds all these practice dimensions in its 7proposed model for career counselling interview.

\subsection{SCCT and Career Decision Self-Efficacy}

Social Cognitive Career Theory (SCCT) has emerged as a valid and frequently used framework for understanding academic and career choice in recent years not only in the U.S.A. but in various EU countries (Betz, 2008; Brown, et al., 2008,2011; Sheu et al., 2010; Sheu \& Bordon, 2017). 
SCCT draws its roots from Bandura's social cognitive theory, which emphasizes the importance of examining the ways in which self-referential thinking, cognitive patterns, and various social processes interact to guide and influence human behavior (Bandura, 1986; Lent et al., 1994). The initial theorists of SCCT, Lent et al. (1994), adapted the elements of Bandura's social cognitive theory that were most relevant to career development processes in order to examine the influence and interaction between experiential learning processes and cognitive processes on career decisions. Three central constructs have been identified by SCCT due to their relevance within career development processes: self-efficacy, outcome expectations, and goals (Lent, Brown, \& Hackett, 2002). Self -efficacy is defined as a self-evaluation of one's abilities to complete a certain task or attain a certain level of achievement or performance (Bandura, 1986). Self-efficacy belief might improve or weaken through different ways. For instance, students who have never experienced career decision-making will most probably have lower self-efficacy belief in career decision-making.

According to Lent, Brown \& Hackett (2002), self-efficacy is a core component of SCCT theory, because people are theorized as more likely to develop an interest in activity, choose to pursue that activity, and ultimately perform better at the activity if they possess robust self-efficacy beliefs (assuming the individual also possesses requisite abilities and receives support from their environment) (Wu, 2018). According to Scott and Cianni (2008), research on career decision self-efficacy adds to our understanding of the nature of career decision making and enhances knowledge of many constructs relevant to the study of career development. Lent and Brown's (2013) new social cognitive career theory of career management, covers a wide variety of adaptive career-related behaviors used by people to adapt to occupational and personal contexts throughout their life-span).

In development process, career decision self-efficacy refers to the individual's belief that he or she can successfully complete tasks necessary to career decision making (Taylor \& Betz, 1983). Taylor and Betz developed the Career Decision making Self-efficacy scale to measure this construct and showed that it was associated with career indecision. The questionnaire asks the respondents to state their beliefs whether they can successfully complete tasks necessary to career decision making concerning: 1) career exploration, 2) realistic self-appraisal skills, 3) goal selection, 4) planning skills and 5) problem solving capabilities.

Within SCCT framework, research seeking to promote the understanding of contextual influences in career decision making self-efficacy, also investigates the influence of parental behavior in career decision-making process. On the basis of two potentially complementary theories, the theory of attachment (Bowlbey, 1969,1973,1982) and the social-cognitive career theory SCCT -Lent, Brown \& Hackett, 1994,2000) (Dowing \& Nauta, 2010; Wright, 2017; Wright \& Perrone, 2008,2010). Social Cognitive Career Theory provides a specific and acceptable framework suitable for research including the embodiment of the principles of the Bond Theory in the process of career development. The theoretical point of complementarity refers to the role played within the relationships of the individuals with important persons of their environment from childhood, particularly with parents and the influence which is brought to bear on the career development of the individual (especially in the development of the sociocognitive mechanisms: the views of self-efficacy and the expectations for the results). The turn of the research interest towards this direction led to empirical findings in relation to the effect of the types of bonds with the parents (safe or unsafe (type of bond with the parents) in the process of career decision-making internationally (i.e. Blustein et al., 1989; Braunstein -Bercovitz et al., 2012; Charokopaki, 2012; Dowing \& Nauta, 2010; Koumoundourou and Mitsou, 2014; Lease \& Dahlbeck, 2009; O' Brien Fredman, Tipton \& Lim, 2000; Ryan, Solberg \& Brown, 1996; Wright \& Perrone 2010; Wright et al., 2014; Wright 2017) and as a result the establishment of the potential complementarity of two theories.

\subsection{Information Sources of Self-efficacy}

Self-efficacy includes an empirically produced theory of its rationale which is based on four very important enhancing procedures (sources of information). According to the research carried out by Bandura $(1986,1995)$ the main sources out of which the individual's self-efficacy is provided are thought to be: past performance experiences, vicarious learning, verbal persuasion and emotional state and emotions regulations techniques. Career counsellors use these procedures in order to design the appropriate counselling intervention and set the appropriate goals (e.g. to develop or reform these beliefs).

In particular, the individual's paste performance experiences are the most important informational source of self-efficacy beliefs. Both experience and research have shown the central role of the personal achievements in the formation or the strengthening of the self-efficacy beliefs. High levels of self-efficacy beliefs which combine with successes in the outcome of specific actions maximise the possibility of adopting such attitudes while the opposite happens in cases of a negative outcome of specific actions. Vicarious learnings is obtained by following 
models, that is, other human beings who carry out certain actions. When the counsellor indicates his/her client with models who have successfully managed aspects of career decision-making gives him/her the possibility to identify himself/herself and thus strengthens his/her possibilities too. Particular care must be given to the characteristics that this 'model' should have, so as the positive results for the client are maximised (e.g. ethnic identity, age, gender, social class, professional ability e.t.c.).

Emotional state and emotions regulation techniques concerning a project or a series of specific actions, inform the client for the anticipated success or failure of the outcome of such an action. When humans experience negative emotions (i.e fear, or anxiety) regarding their abilities, their emotional responses could reduce beliefs of self-efficacy and add additional negative emotions. Finally, the verbal regulations techniques (verbal persuasion) refer to the verbal encouragement or discouragement which comes out of the social environment during the specific actions. Supportive messages could help someone (i.e. the client) to insist on activities which created emotions of anxiety or fear in the first place (Lent, Hackett, \& Brown, 1999).

\subsection{Comparative and Critical Review of Career Counselling Theories}

In the present article, the author drew on narrative career counselling and in particular on story telling approach and social cognitive career theory, as the conceptual framework for the qualitative structured interview process. Despite the different theoretical and philosophical basis of approaches mentioned, a sustainable structured model of the career counseling interview could be constructed, guided by the complementarities of both. This consideration expands and strengthens the methodological validity of the proposed structured model and consequently may enhance the possibilities of the counselling process respectively.

The first point of complementarity and comparative approach of our study refers to the subject of possible reforming of vocational identity of the individual and to processes referring to it, such as decision-making process. Within narrative approach, the composition of the career identity is examined within the wider cultural, historical and social context of the individual (McMahon \& Patton, 2006; Meijers \& Lengelle, 2012). The elements and parameters that are recognised as important within this theoretical framework and refer to career decision-making, play a very decisive role, not only during the process per se, but also in the result of it (content of decision) even in different way each time (Young \& Collin, 2004). However, the consideration of social context for the individual is not static. Narrative approach considers individual's interaction with the given, objective, and established social context that becomes in such a way, so that the last is reconstructed and set up from this interaction (Campell \& Ungar, 2004; Nightingale, \& Cromby, 2002). As far as the socio-cognitive approach is concerned, self-efficacy beliefs that an individual form, interact with his/her environment, with other cognitive mechanisms (e.g. outcome expectations and agency) and with the conception of abilities, skills and achievements of the individual (Bandura,1997). In this way, humans can be producers as well as the modulators of their environment (Lent, Brown \& Hackett, 1996).

Putting the previously mentioned processes together, we can conclude that in both approaches the consideration of construction of vocational identity and one of its basic elements, career decision-making process, is identified and formed from the influences of the complex social context. However, both approaches consider the interaction between the individual and this context, which means they believe in the ability of the individual to change, to develop and mainly, to self-regulate itself despite social context influences. Moreover, they recognize the social context to be reconstructed in its way too.

Despite the complementarity of the two approaches as far as the formation of vocational identity is concerned, we have considerable differences referring to the process of (re)construction of the cognitive process of decision-making. Within the narrative approach, narration as a basic psychological operation, contains the power of metamorphosis (Bujold, 2004) which comes from the comprehension, interpretation and understanding of the relevant decision-making experiences (Tsergas, 2015). This process helps the individual to identify, benefit from its abilities and, as a consequence, change -if necessary- the way of decision-making during its career. Within social cognitive career theory the central cognitive mechanisms (belief of self-efficacy and outcome expectations) can be developed or modified after the appropriately designed interventions that focus on the four information sources (enhancing procedures) as mentioned above (Lent, Brown \& Hackett, 1996; Lent, Hackett \& Brown, 1999).

The subjective dimension of understanding the personal experiences that consist careers of the individuals and affect the way their beliefs are formulated in important subjects such as the process of career decision-making, is a second point of complementarity of the two approaches. Within narrative approach, which adopts the theoretical foundations of constructivism and social constructivism, narration of stories (story telling) is a process which helps individuals develop their cognitive mechanisms and self-efficacy beliefs about 
decision-making. The content of these beliefs differs from one person to another, because of the subjective dimension with which individuals perceive their life and career experiences and the different meaning given to them (Peavy, 1998). According to the social cognitive theory, self-efficacy is one the basic cognitive mechanism defines agency to humans which includes assumptions of subjective forecast for specific areas of action. It refers to the beliefs of individuals about how it could deal with the demands of a specific role or to what degree could successfully complete a specific activity (Bandura, 1986). In this way, every person has its own self-efficacy beliefs referring to different possible areas of action.

Despite the similarities mentioned, time definition is an essential difference between the two approaches for the cognitive construct of career decision-making and its content. Within the narrative approach, understanding the meaning of experiences is achieved in the present time (the time of career counselling process) despite the fact that it concerns experiences of the past. Within social cognitive approach, self-efficacy beliefs are the ones that the individuals have in the present time (the time career counselling process occurs) concerning possible actions of the immediate or distant future. However, human beings could rely on previous experiences in order to achieve a dynamic review of their future professional roles. In this way, the two approaches could operate complementarily to form the cognitive mechanisms of an individual in a career counselling process.

A third point of complementarity and comparative approach of our study refers to the relationship between the decision-making process and the behaviour of the individual. Within the narrative approach, stories referring to decision-making process and their importance as defined by the individual within the counselling procedure, become the guide for his/her future actions (Rushdie, 2010). This planning of actions makes the individual ready to make decisions and to implement them, whatever transitions there will be needed (Colin, 1990; Cochran, 1991; Mc Adam et al., 2001; Peavy, 1998). Self efficacy beliefs concerning career decision-making, although they refer to the assumptions of the individual for his/her future actions, they influence his/her actions in the present since they define the quantity of the effort and the duration of persistence which the individual shows and of course the results/consequences of these actions (Bandura, 1982, 1997; Lent \& Hackett, 1987). Self efficacy beliefs (and outcome expectations) comprise one of the central mechanisms through which human beings formulate their behaviour.

\section{Methodology}

The author's aim was to develop a model that would provide a practical example for career counsellors about how to use quantitative career assessment in narrative and story telling approaches to career counselling, concerning career decision making process. Within the social cognitive career theory, career decision making self-efficacy is the core construct toward which counseling interventions should be addressed. Counselors might use self-efficacy sources of information (i.e. mastery experiences, vicarious learning, social persuasion and emotions regulations techniques) in order to facilitate individual's career development and awareness (Lent et al.,1996; Lent et al.1999). The Integrated Qualitative Structured Model presented below (see Table 1) facilitates and enables exploration of career decision making self-efficacy beliefs, through the use of story crafting questions based on the four sources of efficacy information for an interactive process between career counselor and client.

\subsection{Rationale}

This article considers the potential complementarity between the narrative career counseling and story telling approach and the social cognitive career theory and describes a qualitative Structured Interview Process to construct stories about career decision making self-efficacy. Career assessment may seem unrelated to, disconnected and fragmented from the individual's life experiences or experiences concerning career decision making. Thus, there are a few models to guide counsellors in integrating narrative career counselling with quantitative career assessment processes (see above: Maree, 2014;2019; McMahon \& Watson, 2012; Savickas, 2011a; b; Hartun, 2015; Hartung and Santilli, 2018).

Authors' challenge was to facilitate the connectedness between career assessment and stories to experiences related to career decision making narrated by individuals. In this regard, there is an opportunity for career counselors to translate quantitative information provided by career assessment instruments into qualitative understanding that supplements clients' knowledge and understanding of contextual influences concerning career decision making (McMahon \& Watson, 2012). Up to now in international literacy and in our country (namely: Greece), we have acknowledged proposals to design the appropriate counselling intervention in order to develop or (re)contract career decision-making self-efficacy beliefs individually or in group settings, by gradually engaging individuals in activities concerning decision-making process (i.e. Bernes, Bardick, \& Orr, 2007; Charokopaki, 2012,21015a,2015b,2016; Koumoundourou, 2015; Reese \& Miller, 2006;2007;2010). To the best 
of present author's knowledge, there is no suggested model to guide exploration, help individuals reflect (and reflect on their reflections) their career-life decision making stories and overcome problems related to career indecision through the development and (re)construction of career decision-making self-efficacy beliefs.

The proposed initiative, aspires to become a model for career counsellors and researchers of career counselling and it responds to calls in international bibliography for integration of current dynamic approaches like narrative and classic quantitative psychometric methods in the management of career decision making (Argyropoulou \& Kaliris, 2018; Maree, 2014;2019; McMahon \& Watson, 2012; Savickas, 2011a;b; Hartung, 2015; Hartung and Santilli, 2018).

\subsection{Use}

People often need help planning and deciding about their career choices. Within the new social framework of life-long learning, individuals will need to reshape not only their careers but also their lives. As a result, the process of career decision-making appears to be crucial and important aspect of their career development. Self-efficacy beliefs define the intention of individuals to engage in a specific project/process as well as the quality of their effort. Those who have positive self-efficacy beliefs are not afraid to get involved in the process of career decision-making, they try and they do not give up when they meet difficulties. Low self-efficacy beliefs are possible to diminish the effective operation of the cognitive mechanisms which are activated during the decision making process, with negative extensions: absence of engagement in the career decision making process, restricted behaviour of career investigation (Blustein, Ellis \& Devenis, 1989; Gushue et all., 2006), restriction of the ability to develop knowledge and skills as well as non-achievement of self assessment for those abilities which would help the individual to effectively deal with the process of decision-making in the future (Taylor \& Betz, 1983; Taylor \& Pompa, 1990).

Humans make up themselves and their worlds through the stories they tell (McAdams, 1985). To achieve decision making success and decision outcomes that fit best individuals thoughts, feelings, desires, interests and goals individuals must create stories about themselves that express clearly their sources of efficacy information: past performance experiences that reveal personal achievements in the formation or the strengthening of the career decision making self-efficacy beliefs, vicarious learning obtained from following models, emotional state and emotions techniques and verbal regulations techniques (verbal persuasion) referring to verbal encouragement or discouragement which comes out of the social environment.

The Integrated Qualitative Structured Model aims to help individuals construct stories about career decision making self-efficacy. It offers a sort of "narrative mirror" (Hartung and Santilli, 2018) individuals may hold up to look at their past of career decision making. By looking closely to this mirror, they can reflect on the success or failure of past, meaningful to their specific actions, the completion of these actions or confrontation of the same past situations. Narrative career counselling will also provide client with a more unified sense of his/her life experiences connected to career decision making (Campbell \& Ungar, 2004). More specifically, since narration values the subjective attribution of meaning in the experiences narrated, career decision making themes identified during career counseling in the context of the client's experiences in past stories, enable connectedness between stories that may have been previously viewed as disconnected or discrete events (Gergen \& Gergen, 2006). These themes will constitute an effective intervention in the attribution patterns of self-efficacy beliefs.

Attribution patterns are often considered as the causes of the good or bad effects of the actions of the individuals. In this way, they are considered as distortive filters of their perception of their abilities and should be altered. The client with telling, reflecting and dialogically exploring of his/her stories concerning career decision-making or other decisions in his/her past life, will afford an opportunity to identify possible distortive filters about his/her efficacy beliefs. This procedure leads to the reconstruction of self-efficacy beliefs because the client realizes that real causes of the results of his/her actions are his abilities, skills, knowledge and other characteristics and not external random causes, are the real causes of the results of his/her actions (Lent et al., 1996; Lent et al., 1999). Constructing and reflecting on answers to the questions of the Interview (their stories), with valued audience such as career counsellor, empowers individuals to pursuit of their decisions and believe that they are capable of achieving them successfully so they can become the authors of their own career and life decisions and confront uncertainty for the future and problems which exist when taking career decisions.

Another aspect is that concern has been expressed though that narrative approaches toward assessment could prove time-consuming (e.g. Sampson, 2009). The Integrated Qualitative Structured Model can be completed within one up to three career counselling sessions, following the completion of the Career Decision Making Self-Efficacy Scale and the appropriate scales to identify the type of adult bond (avoidance, ambiguous/anxious). Alternatively, it can be used in groups of two or more clients exploration of career decision making self-efficacy 
beliefs can be facilitated around the story crafting questions. Finally, although the model was developed to address adult clients -from early adulthood to late maturity, it can be adjusted for students attending secondary education as well.

\subsection{Content}

Table 1 presents the Structured Interview Process. Story crafting questions aim to translate the quantitative information of Taylor and Betzs' career decision making self-efficacy scale score into qualitative understanding that supplements clients' self-knowledge about career decision makings self-efficacy beliefs. Also, story crafting questions for each source of efficacy information (i.e. past performance experiences, vicarious learning, verbal persuasion and emotional state and emotions regulations techniques) aim to invite clients to understand experiences and other contextual influences concerning career-life decision making. Consistent with other narrative approaches, story telling values constructing a relationship that provides a reflective space in which the client and counselor engage in a respectful dialogical exploration of client's story/ies (McMachon, 2005;2006;2007;2009; McMachon \& Watson, 2010,2012). Career counsellors become facilitators of a process in which they model a genuine curiosity to find out more about individuals' career decision making experiences (Bujold, 2004; McMahon \& Watson, 2012).

\subsection{Story Crafting}

In facilitating story telling of the career assessment process, the career counselor encourages and facilitates the core practice dimensions of client agency, meaning making, reflection, learning and connectedness. A set of story crafting questions that operationalize these practice dimensions so that stories of the client's career decision making self-efficacy can be crafted are provided in the Structured Qualitative Interview found in Table 1.

Table 2 provides a more detailed understanding of the integration of story-telling, story crafting questions and sources of career decision makings self-efficacy information for almost all questions. In this table, each of the story crafting questions operationalizes elements of career decision making self efficacy and also dimensions of the story telling approach. Connectedness is operationalized by questions that discover elements of self- efficacy referring to the career decision-making in various aspects of the individual's life which ask for connection with the past and present experiences in contexts such as school, work, and family. The dimension of reflection is operationalized by questions that explore emotions, attitudes, types of behaviour or other experiences in relation to career decision making self-efficacy beliefs. Meaning making is operationalized by questions provoking the client to draw conclusions about relationships between the elements of apparently different stories of life or career that the client has already narrated. Learning is an important dimension of story-telling that generalizing meaning into other life contexts. Finally, agency is fostered through questions that invite the client to plan and narrate one or more stories which would include future activities concerning career decision making (McMahon $\&$ Watson, 2012; Patton McMahon, 2006).

\subsection{Quantitative Assessment}

In the present model, besides narrative exploration of standardized scores offered by traditional career assessment (i.e. the translation of quantitative information provided by career assessment instruments into qualitative understanding) we suggest the use of quantitative methods (i.e. career assessment instrument of career decision-making self-efficacy and appropriate scales to identify the type of adult bond (avoidance, ambiguous/anxious) for other purposes.

Instruments can be applied in the beginning of the counselling process for the early assessment of career decision-making self-efficacy beliefs and after the completion of counselling process (Reese \& Miller, 2006,2010). The use of the scale of career decision making self-efficacy beliefs in the beginning of counselling process provides assessment of the level of self-efficacy beliefs. The use of the same scale at the end of the counselling process ensures the effectiveness of the applicable programme and its techniques (Kaliris \& Kriwas, 2014).

Use of the appropriate scale to identify the type of adult bond from career counsellor aims to assess the nature and the quality of the clients' relations with his/her parents so that possible factors that suspend the readiness of the client to engage and perform tasks related to career making decisions can be identified (Wright \& Perrone, 2008,2010). In the integrated model between Attachment Theory and Social Cognitive Career Theory, the type of affective relations that the client had with his/her parents/guardians in his/her childhood, shape to a very large extend, the way in which he/she assesses and estimates him/herself, as well as all the areas and activities among which is his/her career development is developed. During counselling sessions, counsellor can provoke story crafting questions that supplements clients' knowledge and understanding of the influences derive from the 
nature and the quality of the clients' relations with his/her parents. Examples of such questions are presented in Table 1, in the second and third source of enhancement (vicarious learning and emotional state). Persons mentioned as models may belong to family environment of the client or his/her generation chart.

Using qualitative methods like questionnaire together with new, narrative techniques provide validity and credibility to the integrated model (Kriwas, 2011). Several findings from experimental research provide evidence that the combination of quantitative and qualitative methods foster a profound understanding of the subjects operationalized in the counselling process (Pratt, Arnold \& Mackey, 2001).

Table 1. Integrated Qualitative Structured Interview Process

Integrated Qualitative Structured Interview process using story crafting questions.

The following questions for every source of enhancement invite participants to craft stories around the four sources of career decision making self-efficacy information in a structured interview process.

\section{Starting Questions}

- What is your standardized score for career decision making self-efficacy beliefs?

- How would you explain this score?

\section{Story crafting questions about: Past Performance Experiences}

1. Could you remember a personal past performance experience of your own life and the roles you play in it?

2. Could you remember a personal past performance experience in your studies, education or training?

3. Could you remember a personal past performance experience in your work?

4. Could you remember a personal past performance experience concerning career decision-making? (in general)

5. Could you remember a personal past performance experience concerning the solution of a problem in your life or your work?

6. Could you remember a personal past performance experience relating to the search and finding of information about professions, career or the world of work?

7. If you needed to assess using a scale from 1 to 10 (where 1 is the minimum and 10 is the maximum) how would you assess your above past performance experiences?

8. How do you interpret this assessment of your most important past performance experiences?

9. Which personal abilities, skills, personality characteristics could you recognise as the most important of your past performance experiences?

Note: The above questions are posed by the counsellor for separate sections concerning the life and career of the client. In other words, the questions are repeated for personal past performance experiences in work, career, decision-making, vocational information and the solution of a problem.

10. In what way these abilities, skills, personality characteristics have influenced your life?

11. Which of these elements could you identify in your personal life and the roles you have today (i.e. as a child, parent, companion, etc.)?

12. Which of these elements could you identify in the roles and the duties you have today in your career?

13. Which of these elements could you identify in the roles and the duties you have today in your work?

14. Concerning the competences which give you the roles you have in life and in your work which do you think offer you more and which less satisfaction?

15. Based on the reflection you made in relation to your personal past performance experiences in the various sections of life and work and in the subject you referred, what would you like to achieve in the future in relation to your work that will offer you the maximum satisfaction?

\section{Story crafting questions about: Vicarious Learning (contact with models)}

1. Could you remember a person from your close family environment who became a model for you during your childhood?

2. How do you interpret your admiration for this person? 
3. Is there a subject in the life, the work, or generally in the career of this person which you think he managed with success? (i.e in terms of decision-making, solution of a problem, setting goals, planning his/her life or / and his/her career)?

4. Could you describe the competences, work duties (professional duties) of this person? If not, do you think that it is possible for you to find relevant information?

5. What abilities, skills, and personality characteristics, values, interests and other elements you admired/appreciated (then and today) in this person?

6. Which of these elements do you think you, yourself have?

Note: the above questions are repeated for person/s which constitute a model for the client from his close environment (social, professional, wider family environment, etc).

7. In what way do you think each one of these persons influenced the decisions of your life?

8. In what way do you think each one of these persons influenced the decisions in relation to your work and in general your career?

Note: The questions from number 2 to number 8 are repeated in case the client has mentioned more than one person which constituted a model for him/her from his/her wider family or social environment.

9. What connection do you think there could be between this person or persons and the various aspects of your life?

\section{Following questions:}

10. Could you mention a person which is a model for you today?

Note: The questions from number 2 to number 9 are repeated for the person that will be mentioned. In case there is more than one person mentioned as models, the questions are repeated.

11. Which is your favourite film? (novel, magazine, or TV series)

12. Who is your favourite hero/heroine in that?

Note: The questions from number 2 to number 9 are repeated for the favourite hero/heroine of the client. In case he/she has more than one person as a favourite hero/heroine in a different section, the questions are repeated again.

Finally, when all the client's models have been discussed:

13. If you should have to assess, using a scale from 1 to 10 (where 1 is the minimum important and 10 the maximum important) how would you assess each one of the above models?

14. How do you interpret this assessment?

15. Based on the reflection you have made in relation to the models you have, in what way do you think the three most important of your models influence the goals you have for the future relating to work?

\section{Story crafting questions about: Emotional State (emotion regulation techniques)}

1. Could you narrate three of your memories which relate to your relationship with the parents / guardians during your childhood?

2. How (in what way) do you explain the choice of these memories?

3. If you should have to assess, using the scale from 1 to 10 (where 1 is of minimum importance and 10 of maximum importance) how would you assess each one of the above memories?

4. How do you interpret this assessment?

5. In what way do you think these memories influenced your life?

6. In what way do you think these memories influenced your work or your career in subjects such as: choice of goals, decision-making, planning of your activities and solution of problems?

7. What emotions could you remember and recognise in these memories?

8. How did you regulate these emotions

Note: the above question is only asked in case of negative emotions such as fear, anger, anxiety, etc.

9. What emotions are created within you at the recollection of these memories this present moment? 


\section{Following questions:}

10. Could you narrate three of your memories when it was necessary to search for vocational information (relating to your studies, professions and the labour market)?

11. If you had to assess, using the scale from 1 to 10 (where 1 is of minimum importance and 10 of maximum importance) how would you assess each one of the above memories?

12. How do you interpret this assessment?

13. What emotions can you remember and you could recognise in the most important of your memories?

14. How did you regulate those emotions?

Note: the above question is asked only in case of negative emotions such as fear, anger, anxiety, etc.

15. In what way do you think this memory influenced your work or the direction of your career?

16. In what way do you think these emotions influence your work or your career today?

\section{Following questions:}

17. Can you narrate three memories when you needed to put a target in relation to your work, or your career? (i.e to make a decision for your studies or your education, to choose a profession or a speciality, to look for work, etc.).

Note: There follow questions 11 to 16 .

18. Can you narrate three of your memories when it was necessary for you to plan something relating to your work or your career? (i.e. to write a curriculum vitae, to make a schedule for the next period of time, to look for work, to give a staff selection interview, to decide if you are going to continue with your studies, etc.)

Note: There follow questions 11 to 16 .

19. Could you narrate three of your memories in case it was necessary to solve one or more problems in relation to your work or your career? (i.e. to plan a strategy for dealing with the failure in the execution of a project, to change professional activity, to implement a new educational programme, to resist attempts of your family environment to persuade you into something, etc.,).

Note: There follow questions 11 to 16 .

\section{Story crafting questions about: Verbal persuasion}

1. Could you remember and narrate a supportive comment (i.e. reward) or discouraging comment (i.e. negative criticism) that was made to you by someone when it was necessary for you to search for information relating to your studies or the professions?

2. In what way do you believe this comment influenced you in general or more specifically in your work and in the direction of your career?

3. What emotions you could remember and recognise in the specific memory?

4. Does this supportive comment influence you today? If yes, in what way?

\section{Following questions:}

5. Could you remember and narrate a supportive or discouraging comment someone made to you when it was necessary for you to set up a goal in relation to your work or your career? (i.e. to make a decision for your studies or your education, to choose a profession or speciality, to look for work, etc.)?

Note: Questions 2 to 4 are repeated.

6. Could you remember and narrate a supportive or discouraging comment someone made to you when it was necessary for you to plan something in relation to your work or your career? (i.e. to write a curriculum vitae, to make a schedule for the next period of time, to search for work, to give a selection interview, to decide if you are going to continue to a new circle of study, etc.).

Note: There follow questions 2 to 4

7. Could you remember and narrate a supportive or a discouraging comment that someone made to you on occasions when it was necessary to solve one or more problems relating to your work or your career? (i.e. to design a strategy for dealing with the failure in the execution of a project, to change professional activity, 
to implement a new educational programme, to resist attempts of your family environment to persuade you for something, etc.).

Note: There follow questions 2 to 4

\section{Following questions}

8. If you had to assess using a scale from 1 to 10 (where 1 is of minimum importance and 10 of maximum importance) how would you assess each one of the above supportive comments you have received?

9. How do you interpret such an assessment?

10. Is there another supportive or discouraging comment someone made to you relating to some other subject relating to your work or career?

Note: The following questions are asked in case the beneficiary answered question 10.

11. In what way does this comment influence you today?

12. In what way do you think this comment will influence you in the future?

13. Based on the reflection you made relating to the supportive comments you have received up to today for subjects that were mentioned, what would you want to comment about the meaning or importance these comments have for you?

Note: The questions relating to the Verbal Persuasion are possible to be asked separately for the supportive comments and separately for the discouraging comments that the client has received.

Table 2. Story-crafting questions, Career decision making self-efficacy (subscales) and Story Telling

\begin{tabular}{|c|c|c|}
\hline $\begin{array}{l}\text { Story-crafting } \\
\text { questions }\end{array}$ & $\begin{array}{c}\text { Subscales of } \\
\text { Career decision } \\
\text { making self-efficacy beliefs }\end{array}$ & Story Telling \\
\hline \multicolumn{3}{|c|}{ Past Performance experiences } \\
\hline 1 & Self esteem & Reflection \\
\hline 2 & Self esteem/ Career Planning & Reflection \\
\hline 3 & Solving & Reflection \\
\hline 4 & Self Esteem/ Decision-making & Reflection \\
\hline 5 & Self Esteem/ Problem Solving & Reflection \\
\hline 6 & Self Esteem/ Professional Information & Reflection \\
\hline 7,8 & & Meaning making \\
\hline 9 & Self esteem & Reflection/Meaning making \\
\hline $10,11,12,13$ & Self esteem & $\begin{array}{c}\text { Connectedness/ Meaning making / } \\
\text { Learning }\end{array}$ \\
\hline 14 & Self esteem & $\begin{array}{l}\text { Reflection/ Meaning making / } \\
\text { Learning }\end{array}$ \\
\hline 15 & & Self-determination (agency) \\
\hline \multicolumn{3}{|c|}{ Vicarious Learning (contact with models) } \\
\hline 1 & & Reflection \\
\hline 2 & & Meaning making \\
\hline 3 & $\begin{array}{c}\text { Career planning / Problem solution / } \\
\text { Goal selection }\end{array}$ & Reflection \\
\hline 4 & Professional information & Learning \\
\hline 5 & Professional Information & Meaning making / Connectedness \\
\hline
\end{tabular}




\begin{tabular}{ccc}
6 & Self-esteem & Learning / Meaning making \\
7,8 & Self-esteem & Connectedness / Learning \\
9 & Self-esteem & Meaning making / Connectedness / \\
& & Learning \\
$10,11,12$ & & Reflection \\
13,14 & & Meaning making \\
15 & & Self-determination (agency) \\
\hline
\end{tabular}

Emotional State (emotions regulation techniques)

\begin{tabular}{|c|c|c|}
\hline 1,2 & & Reflection / Meaning making \\
\hline 3,4 & & Meaning making \\
\hline 5,6 & & $\begin{array}{c}\text { Connectedness / Learning / Meaning } \\
\text { making }\end{array}$ \\
\hline 7 & Self-esteem & Reflection \\
\hline 8 & & Learning \\
\hline 9 & & Learning / Connectedness \\
\hline 10 & Professional Information & Reflection \\
\hline 11,12 & & Meaning making \\
\hline 13 & & Reflection \\
\hline 14 & & Learning \\
\hline 15,16 & & $\begin{array}{c}\text { Meaning making / Connectedness / } \\
\text { Learning }\end{array}$ \\
\hline 17 & Decision-making & Reflection \\
\hline 18 & Career planning & Reflection \\
\hline 19 & Problem solution & Reflection \\
\hline \multicolumn{3}{|c|}{ Verbal Persuasion } \\
\hline 1 & Professional information & Reflection / Meaning making \\
\hline 2 & Self-esteem & $\begin{array}{l}\text { Meaning making / Reflection } \\
\text { Connectedness / Learning }\end{array}$ \\
\hline 3 & Self-esteem & Reflection \\
\hline 4 & & $\begin{array}{l}\text { Self Determination (agency) / } \\
\text { Connectedness / Learning }\end{array}$ \\
\hline 5 & Target selection & Reflection/ Meaning making \\
\hline 6 & Career Planning & Reflection/ Meaning making \\
\hline 7 & Problem solving & Reflection/ Meaning making \\
\hline 8,9 & & Meaning making \\
\hline 10 & Self-esteem & $\begin{array}{c}\text { Meaning making, / Connectedness / } \\
\text { Learning }\end{array}$ \\
\hline 11,12 & Self-esteem & $\begin{array}{c}\text { Connectedness / Meaning making / } \\
\text { Learning }\end{array}$ \\
\hline 13 & & Self determination (agency) \\
\hline
\end{tabular}

\section{Conclusion}

In the field of career development, there is an acknowledged relationship between career assessment and career counselling. There is also a growing movement toward narrative approaches and a trend for integrating older 
principles and methods in new approaches, including narrative. These trends respond the long-standing concerns about the need for richer understanding of career decision-making of clients in career counselling and deeper understanding of assessment results in relation to individuals' career development.

The Integrated Qualitative Structured Interview model presented, aims to facilitate narrative exploration by crafting stories of elements that reflect the four sources of career decision-making self-efficacy information. For its theoretical basis, we considered the potential complementarity between the Narrative and story telling approach and Social Cognitive Career Theory framework. The proposed model is considered to represent a fresh contribution to the field of career counseling which may serve as a sustainable framework for career counseling researchers and practitioners because of its strong theoretical foundation of these approaches. Comparative and critical review of the approaches presented, consists the theoretical foundation of the model and expand, strengthen its validity and credibility as well as its effectiveness as far as career counseling is concerned.

The model also focuses on how quantitative career assessment can be complemented through the use of narrative career counseling, specifically a story telling approach. Using the Integrated Qualitative Structured Interview process would result in crafting of career decision makings stories that include career assessment scores in a narrative career counselling process. In this regard, using traditional career assessment methods together with new, narrative techniques provide construct validity and credibility of the integrated model.

The Integrated Qualitative Structured Interview model aims to enable narrative exploration to supplement clients' knowledge and understanding of the role of past and present influences concerning career decision making self-efficacy. Individuals with positive self-efficacy beliefs are not afraid to get involved in the process of career decision-making, they try and they do not give up when they meet difficulties. Their engagement with the process of career decision-making give them the opportunity to be able to control -to a large extent- the process (as well as the content of the decisions or preferences) and in this way to understand the ability to exercise personal control in those processes.

The client is invited to tell, reflect and dialogically explore his/her stories concerning career decision-making or other decisions in his/her past or present life. Constructing and reflecting on answers to the questions of the Interview (clients' stories), with a valued audience such as career counsellor, finally empowers individuals to pursue of their decisions. It makes them believe that they are capable of achieving their goals successfully so they can become the authors of their own career and life decisions and confront uncertainty for the future and problems which exist when taking career decisions. Story crafting questions are also designed to support individuals in the process of reconstructing their career decision makings self-efficacy beliefs and set (new) goals, design their paths for the future actions to achieve these goals. Finally, they promote their narratability skills.

In sum, the Integrated Qualitative Structured Interview, could be useful for the development, modification, construction or reconstruction of meaning in a reflective framework for career decision-making self-efficacy beliefs of a client in career counselling. Finally, it could be used in research aimed at examining career decision making indicators and contextual influences of adult individuals.

\section{Future Research Directions}

Including the traditions of career assessment and the growing movement toward narrative approaches, the integrated qualitative structured interview represents a significant challenge in the field of career counseling. Future research is needed to thoroughly and critically examine the validity of the Integrated Qualitative Structured Interview for its use as a guided narrative career interview. Suggested avenues for study include testing the model as an intervention to increase (reconstruct) career decision making self-efficacy beliefs. Future research should also examine the effect of the model on improving client's narratability skills. Future studies using this model could also be conducted to examine individuals' perceptions about the impact and usefulness of the model for empowering individuals to pursuit of their decisions and believe that they are capable of achieving them successfully putting their career goals into actions.

\section{Declaration of Conflicting Interests}

The author declared no potential conflicts of interest with respect to the authorship and/or publication of this article.

\section{Funding}

The author(s) received no financial support for the research and/or authorship of this article.

\section{Acknowledgements}

I would like to thank Vivi Karouzou for his invaluable contribution in proofreading the text. 


\section{References}

Amundson, N. E. (2009). Active engagement: The being and doing of career counselling ( $3 r d$ ed.). Richmond, Canada: Ergon Communications.

Argyropoulou, K. \& Kaliris, A. (2018). From career decision making to career decision management: New trends and prospects for career counseling. Advancies in Social Sciences Research Journal, 5(10), 483-502. https://doi.org/10.14738/assrj.510.5406.

Bandura, A. (1986). Social foundation of thought \& action: A cognitive theory. Englewood Cliffs.

Bandura, A. (1995). Guide for constructing self-efficacy scales. Retrieved March 8, 2001, from http://www.emory.edu/EDUCATION/mfp/bguide/.html

Bandura, A. (1997). Self Efficacy: The exercise of control. New York: W.H. Freeman.

Bernes, K. B., Bardick, A. B. \& Orr, D. T. (2007). Career guidance and counseling efficacy studies: An international research agenda. International Journal of Educational and Vocational Guidance, 7, 81-96. https://doi.org/10.1007/s10775-007-9114-8

Betz, N. E. (2008). Advances in vocational theories. In S.D. Brown \& R.W. Lent (Eds.). Handbook of counselling psychology, 357-374. New York, NY:Wiley.

Betz, N. E. (2000). Self-Efficacy Theory as a Basis for Career Assessment. Journal of Career Assessment, 8 , 205-222. https://doi.org/10.1177/106907270000800301

Blustein, D. L., Ellis, M. V. \& Devenis, L. E. (1989). The development and validation of a two-dimensional model of the commitment to career choices process. Journal of Vocational Behavior, 35, 342-378. https://doi.org/10.1016/0001-8791(89)90034-1

Blustein, D. L. \& Flum, H. (1999). A self-determination perspective of interests and exploration in career development. In M. L. Savickas \& A. R. Spokane (Eds.). Vocational interests: Meaning, measurement and counseling use, 345-368. Palo Alto, CA: Davies-Black.

Bowlby, J. (1969/1982). Attachment and loss. Vol. 1: Attachment. Basic Books, New York.

Bowlby, J. (1973). Attachment and loss. Vol.2: Separation. New York: Basic Books.

Braunstein -Bercovitz, H., Benjamin, A. B., Asor Sh. \& Lev, M. (2012). Insecure attachment and career indecision: Mediating effects of anxiety and pessimism. Journal of Vocational Behavior, 81, 236-244. https://doi.org/10.1016/j.jvb.2012.07.009

Brown, D. (2002). Introduction to theories of career development and choice: Origins, evolution and current efforts. In D.Brown \& Associates, Career choice and development, 3-23. San Francisco, CA: Jossey-Bass.

Brown, D. \& Brooks, L. (1996). Introduction to theories of career development and choice: Origins, evolution and current efforts. In D. Brown \& L. Brooks \& Associates. Career choice and development, 1-30. San Francisco, CA: Jossey-Bass.

Brown,S.D., Lent, R.W., Telander, K. \& Tramayne, S. (2011). Social Cognitive career theory, conscientiousness, and work performance: A meta-analytic path analysis. Journal of Vocational Behavior, 79, 81-90. https://doi.org/10.1016/j.jvb.2010.11.009

Brown, S.D., Tramayne, S., Hohra D. Telander, K., Fan, X. \& Lent, R.W. (2008). Social cognitive predictors of college student's academic performance and persistence: A meta-analytic path analysis. Journal of Vocational Behavior, 72, 298-308. https://doi.org/10.1016/j.jvb.2007.09.03

Bruner, J. (1986). Actual Minds, possible worlds. Cambridge, MA: Harvard University Press.

Bujold, C. (2004). Constructing career through narrative. Journal of Vocational Behavior, 64, 470-484. https://doi.org/10.1016/j.jvb.2003.12.010

Cohran, L. (1991). Life-shaping decisions. New York: Peter Lang.

Colin, A. (1990). Mid-life career change research. In R.A. Young \& W.A. Borgen (Eds), Methdological approaches to the study of career, 197-220. New York: Praeger.

Campbell, C. \& Ungar, M. (2004). Constructing a Life That Works: Part 1, Biending Postmodern Family Therapy and Career Counseling. The Career Development Quarterly, 53, 16-27. https://doi.org/10.1002/j.2161-0045.2004.tb00652.x 
Campbell, C. \& Ungar, M. (2004). Constructing a Life That Works: Part 2, An Approach to Practice. The Career Development Quarterly, 53, 28-40. https://doi.org/10.1002/j.2161-0045.2004.tb00653.x

Charokopaki, K. Ar. (2012). Aytoapotelesmatikotita sti diadikasia lipsis ekpaideytikwn kai epaggelmatikwn apofasewn mathitwn/triwn deyterobathmias ekpaideysis: $O$ rolos atomikwn paragontwn kai ypostiriktikwn mixanismwn. Career decision-making self efficacy of secondary education students: The role of personality, environmental factors and contextual supports. Unpublished doctoral dissertation. University of Thessaly, Greece.

Charokopaki, K. Ar. (2015a). Viwmatikes draseis gia ti dieykolinsi tvn diadikasiwn lipsis apofasewn mathitwn/triwn deyterobatmias ekpaideusis kai twn sxetikwn me aytes antilipsewn aytoapotelesmatikotitas: Ena polymetavlito plaisio anaptyksiakis -proliptikis kai therapeytikis symvouleytikis paremvasis. Experiential actions to facilitate the decision-making process of pupils-three secondary education and their perceptions of self-efficacy: A multidimensional framework of developmental-preventive and therapeutic counseling intervention "In: Contemporary Issues of Professional Counseling, Asvestas T., Sidiropoulou-Dimakakou D., Mylonas, A., Koumoundourou G. (Ed.), Athens: Grigoris.

Charokopaki, K. Ar. (2015b). Ekpaideytiko - ereynitiko programa paremvasis gia ti dieykolinsi tvn diadikasiwn lipsis apofasewn mathitwn/triwn deyterobathmias ekpaideysis, tvn sxetikwn me aytes antilipsewn aytoapotelesmatikothtas kai ths symperiforas tous ston tomea ayto. Educational - research intervention program to facilitate the decision-making processes of pupils in secondary education, their perceptions of self-efficacy and their behavior in this field. Review of Counseling and Guidance, 106, 87-128.

Charokopaki, K. Ar. (2016). Theorotiko Plaisio - Methodologia Symvouleytikis paremvasis gia tin antimetwpisi tou fainomenou twn Neets. Theoretical Framework - Methodology of Counseling Intervention to address the phenomenon of NEETs. In: Career Counseling to support NEETs (Young 15-29 Years Outside Employment, Education or Training Structures), E.O.P.P.EP.P.

Cohran, L. (1991). Life shaping decisions. New York, Peter Lang.

De Bruin, K. \& de Bruin, G. P. (2006). Career assessment. In G. B. Stead \& M. B. Watson (Eds.). Career psychology in the South African context, 129-136. Pretoria, South Africa: Van Schaik.

Dowing, H. M. \& Nauta, M. M. (2010). Separation-individuation, exploration and identity diffusion as mediators of the relationship between attachment and career indecision. Journal of Career Development, 36, 207-227. https://doi.org/10.1177/0894845309345848

Gergen M. M. \& Gergen, K. J. (2006). Narratives in action. Narrative Inquiry, 19, 112-121. https://doi.org/10.1075/ni.16.1.15ger

Gibson, P. (2004). Where to from here? A narrative approach to career counseling. Career Development International, 9(2), 176-189. https://doi.org/10.1108/13620430410526201

Guichard, J. (2009). Self-constructing. Journal of Vocational Behavior, 75, 251-258.https://doi.org/10.1016/j.jvb.2009.03.004

Gushue, G. V., Scanlan K. R. L., Panzer, K. M. \& Clarke, C. P. (2006). The relationship of career decision-making self-efficacy, vocational identity, and career exploration behavior in African-American high school students. Journal of Career Development, 33, 19-28. https://doi.org/10.1177/0894845305283004

Hartung, P. J. (2015). Career Indecision. Practice brief. Alexandria VA: American Counseling Association.

Hartung, P. J. \& Santilli, S. (2018). My Career Story: Description and Initial Validity Evidence. Journal of Career Assessment, 26(2), 308-321. https://doi.org/10.1177/1069072717692980.

Holland, J. L. (1997). Making vocational choices: A theory of vocational personalities and work environments $\left(3^{\text {rd }}\right.$ ed.). Odessa, FL: Psychological Assessment Resources.

Kaliris, A. \& Krivas, S. (2014). The contribution of the postmodern approaches to career counseling theory and practice: Their emerging role in a crucial era for the world of work. Retrieved from: http://www.elesyp.gr/index.php/news/drastiriotites

Kriwas, S. (2011). H Afigimatiki proseggisi sti Simvouleyhtiki gia ti Stadiodromia: Dynatotites, Oria, Prakties, Prooptikes. The Narrative Approach to Career Counseling: Possibilities, Limits - Practices - Perspectives. Review of Counseling and Guidance, 94-95, 27-38. 
Koumoundourou, G. (2015). Thewria Desmou kai Diadikasia Lipsis Epaggelmatikis apofasis: Theoritikes diadindeseis, empeirika eyrimata kai kritiki aksiologisi. Attachment theory and social - cognitive career theory: an integrative framework for career counselling. In: Sidiropoulou-Dimakakou, Asvestas, Koumoundourou, Milwna-Kalava (Eds). Contemporary Issues of Career Counselling, Athens: Grigoris

Koumoundourou, G \& Mitsou, P. (2014). Typoi desmou me tous goneis kai antilipseis aytoapotelesmatikotitas: $\mathrm{h}$ sxesi tous me ti diadikasia lipsis epaggelmatikis apofasis. Parental bonding, career decision making self-efficacy and career identity difficulties among Greek Adolescents. Review of Counseling \& Guidance, 101, 197-209.

Lease, S. H. \& Dahlbeck, D. T. (2009). Parental influences, career decision-making attributions, and self-efficacy: Differences for men and women? Journal of Career Development, 36, 95-113. https://doi.org/10.1177/0894845309340794

Lent, R. W. \& Brown, St., D. (2013). Social Cognitive Model of Career Self-Management: Toward a Unifying View of Adaptive Career Behavior Across the Life Span, Journal of Counseling Psychology, 60(4), 557-568. https://doi.org/10.1037/a0033446.

Lent, R. W., Brown, S. D. \& Hackett, G. (1994). Toward a unifying social cognitive theory of career and academic interest, choice and performance (Monograph). Journal of Vocational Behavior, 45, 79-122.https://doi.org/10.1006/jvbe.1994.1027

Lent, R. W., Brown, S. D. \& Hackett, G. (1996). "Career Development from a social cognitive perspective". In: D.Brown, L., Brooks \& Associates (Eds.). Career Choice and Development, 373-421. San Francisco: Jossey-Bass.

Lent, R. W., Brown, S. D. \& Hackett, G. (2000). Contextual supports \& barriers to career choice: A social cognitive analysis. Journal of Counseling Psychology, 47, 36-49. https://doi.org/10.1037/0022-0167.47.1.36

Lent, R. W., Brown, S. D. \& Hackett, G. (2002). Social Cognitive Career Theory. In: Brown D. \& Associates. Career Choice and Development, 255-311. San Fransisco: Jossey-Bass.

Lent, R. W., Hackett, G. \& Brown, S. D. (1999). A social cognitive view of school-to-work transition. The Career Development Quarterly, 47, 197-311. https://doi.org/10.1002/j.2161-0045.1999.tb00739.x

McAdams, D. P. (1985). Power, intimacy and the life story: Personological inquiries into identity. New York, NY: Guilford Press.

McAdams, D. P. (2006). The problem of narrative coherence. Journal of Constructivist Phychology, 19, 109-125. https://doi.org/10.1080/10720530500508720

Maree, J. G. (2014). Poverty and life designing. In Handbook of the life design paradigm: From practice to theory, ed. L. Nota and J.Rossier, 233-248. Boston, MA: Hogrefe.

Maree, J. G. (2018). Advancing career counseling research and practice using a novel quantitative + qualitative approach to elicit clients' advice from within. South African Journal of Higher Education, 32(4), 149-170. https://doi.org/10.20853/32-4-2558.

McMahon, M. (2005). Career counseling: Applying the Systems Theory Framework of career development. Journal of Employment Counseling, 42, 29-38. https://doi.org/10.1002/j.2161-1920.2005.tb00896.x

McMahon, M. (2006). Working with storytellers: A metaphor for career counselling. In M. McMahon \& W. Patton (Eds.). Career counselling: Constructivist approaches, 16-29. Abingdon, England: Routledge. https://doi.org/10.4324/9780203099599

McMahon, M. (2007). Life story Counselling: Producing new identities in career counseling. In K. Maree (Ed.). Shaping the story: A guide to facilitating narrative counselling, 63-72. Pretoria, South Africa: Van Schaik.

McMahon, M. (2009). Career counseling and story telling: Constructing a 21 st century narrative for practice. In H. Ohlsson \& H. Borg (Eds.). Career development, 1-23. New York, NY: Nova Science.

McMahon, M. (2014). New Trends in Theory Development in Career Psychology. G.Arulmani et al. (Eds.). Handbook of Career Development, International and Cultural Psychology, DOI: 10.1007/978-1-4614-9460-7-2, Springer Science +Business Media, LLC 2014.

McMahon, M. \& Patton, W. (2006). Career Counseling: Constructivist approaches. London: Routledge. https://doi.org/10.4324/9780203099599 
McMahon, M., Patton, W. \& Watson, M. (2005). My System of Career Influences. Camberwell: Australian Council for Educational Research.

McMahon, M. \& Watson, M. (2010). Story telling: Moving from thin stories to thick and rich stories. In K. Maree (Ed.), Career counselling: Methods that work. Cape Town, South Africa: Juta.

McMahon M. \& Watson, M. (2012). Telling Stories of Career Assessment. Journal of Career Assessement, 20(4), 440-451. https://doi.org/10.1177/1069072712448999

Meijersa, F. \& Lengelle, R. (2012). Narratives at work: The development of career indentity. British Journal of Guidance \& Counselling, 40(2), 157-176. https://doi.org/10.1080/03069885.2012.665159

Nauta, M. (2010). The Development, Evolution and Status of Holland's Theory of Vocational Personalities: Reflections and Future Directions for Counseling Psychology. Journal of Counseling Psychology, 57, 11-22. https://doi.org/10.1097/a0018213

Nightingale, D. L. \& Cromby, J. (2002). Social constructionism as ontology exposition and example. Theory \& Psychology, 12(5), 701-713. https://doi.org/10.1177/0959354302012005901

Nota, L, Soresi, S., Ferrari, L. \& Ginerva M.Chr. (2014). Vocational Designing and Career Counseling in Europe. Challenges in Europe. European Psychologist. https://doi.org/10.1027/1016-9040/a000189

O’ Brien, K. M., Friedman, S. M., Tipton, L. C. \& Linn, S. G. (2000). Attachment, separation, and women's vocational development: A longitudinal analysis. Journal of Counseling Psychology, 47, 301-315.https://doi.org/10.1037/0022-0167.47.3.301

Patton, W. \& McMahon, M. (2006). The systems theory framework of career development and counseling: Connecting theory and practice. International Journal of the Advancement of Counselling, 28(2), 153-166.https://doi.org/10.1007/s10447-005-9010-1

Peavy, R. V. (1998). SocioDynamic counselling: A constructivist perspective. Victoria, Canada: Trafford.

Peavy, R. V. (2000). SocioDynamic Perspective and the Practice of Counselling. NATCON Papers, 1-12.

Pratt, M. W., Arnold, M. L. \& Mackey, K. (2001). Adolescents representations of the parent voice in stories of personal turning points. In D.P. McAdams, R. Josselson \& A. Lieblich (Eds), Turns in the road: Narrative studies of lives in transition, 227-252. Washington DC: American Psychological Association.https://doi.org/10.1037/10410-009

Reese, R. J. \& Miller, C. D. (2006). Effects of a university career development course on career decision making elf-efficacy. Journal of Career Assessment, 14, 252-256.https://doi.org/10.1177/1069072705274985

Reese, R. J. \& Miller, C. D. (2010). Using Outcome to Improve a Career Development Course: Closing the ScientistPractitioner Gap. Journal of Career Assessment, 18(2), 207-219. https://doi.org/10.1177/1069072709354309

Ricoeur, P. (1986). Life: A story in search of a narrator. In M.Doeser \& J. Kray (Eds.), Facts and values: Philosophical reflections from Western and non-Western Perspectives, 34-68. Dordrecht, the Netherlands: Nijhoff. https://doi.org/10.1007/978-94-009-4454-1_9

Ryan, N. E., Solberg, V. S. \& Brown, S. D. (1996). Family dysfunction, parental attachment, and career search-self-efficacy among community college students. Journal of Counseling Psychology, 43, 84-89.https://doi.org/10.1037/0022-0167.43.1.84

Sampson, J. P., Jr. (2009). Modern and postmodern career theories: The unnecessary divorce. Career Development Quarterly, 58, 91-96.https://doi.org/10.1002/j.2161-0045.2009.tb00178.x

Sarbin, T.R. (Ed.) (1986). The narrative as a root metaphor for phsychology. In T.R. Sarbin (Ed.), Narrative phychology: The storied nature of human conduct, 3-21. New York: NY: Praeger Scientific.

Sharf, R. S. (2010). Applying career development theory to counseling (5th ed.). Belmont, CA: Brooks/Cole.

Savickas, M. L. (1993). Career Counseling in the postmodern era. Journal of Cognitive Psychotherapy: An International Quarterly, 7, 205-215. https://doi.org/10.1891/0889-8391.7.3.205

Savickas, M. L. (2011a). Career Counselling. Washington, DC: American Psychological Association Books.

Savickas, M. L. (2011b). New questions for vocational psychology: Premises paradigms and practices. Journal of Career Asssessment. https://doi.org/10.1177/1069072710395532 
Savickas, M. L. (2013). Career construction theory and practice. In S.D. Brown \& R.W. Lent (Eds.) Career development and counseling: Putting theory and research to work, 147-183. Hoboken, NJ:Wiley.

Savickas, M. L., Nota, L., Rossier, J., Dauwalder, J. P., Duarte, M. E., Guichard, J. \& Vianen, A. E. M. (2009). Life designing: A paradigm for career construction in the 21st century. Journal of Vocational Behavior, 75 , 239-250.https://doi.org/10.1016/j.jvb.2009.04.004

Scott, A. B. \& Ciani, K. D. (2008). Effects of an undergraduate career class on men's and women's career decision making self-efficacy and vocational identity. Journal of Career Develpement, 34, 263-285. Doi: 10.1177/0894845307311248.

Sheu, H-b., Lent, R. W., Brown, S. D., Miller, M. J., Hennessy, K. D. \& Duffy, R. D. (2010). Testing the choice model of social cognitive career theory across Holland themes: A meta-analytic path analysis. Journal of Vocational Behavior, 76, 252-264. https://doi.org/10.1016/j.jvb.2009.10.015

Sheu, H-b. \& Bordon, J. J. (2017). SCCT Research in the International context: Empirical Evidence, Future Directions, and Practical Implications. Journal of Career Assessment, 25(1), 58-74. https://doi.org/10.1177/1069072716657826

Stebleton, M. J. (2010). Narrative-based career counseling perspectives in times of change: an analysis of strengths and limitations. Journal of Employment Counseling, 47, 64-78.https://doi.org/10.1002/j.2161-1920.2010.tb00091.x

Sullivan, S. E. (2011). Self-direction in the boundaryless career era. In P.J. Hartung \& L.M. Subich (Eds.), Developing self in work and career: Concepts, cases, and contexts, 123-140. Washington, DC: APA Books. https://doi.org/10.1037/12348-008

Super, D. E. (1990). A life-span, life-space approach to career development. In D.Brown \& L.Brooks (Eds.), Career Choice and development: Applying contemporary theories to practice, 197-261. San Francisco, CA: Jossey-Bass.

Taylor, K., M. \& Betz, N. (1983). Applications of self-efficacy theory to the understanding and treatment of career indecision. Journal of Vocational Behavior, 22, 63-81.https://doi.org/10.1016/0001-8791(83)90006-4

Taylor, K. M. \& Pompa, J. (1990), An examination of the relationships among career decision-making self-efficacy, career salience, locus of control, and vocational indecision. Journal of Vocational Behavior, 37, 17-31.https://doi.org/10.1016/0001-8791(90)90004-L

Tsergas, N. (2015). H afigisi stin Epaggelmatiki Symvouleytiki: Nees proseggiseis toy sxediasmou stadiodromias. The narrative in Professional Counseling: New Approaches to Career Design. In: Contemporary Issues of Professional Counseling, Sidiropoulou-Dimakakou, Asvestas, Koumoundourou, Mylonas-Kalavas (Epi.Em.), Athens: Grigoris.

Wright, S. L. (2017). Attachment and self-efficacy in Career Search Activities: A structural Model. Career Development Quarterly, 65(2), 98-112. https://doi.org/10.1002/cdq.12085

Wright S. L. \& Perrone K. M. (2008). The impact of attachment on career-related variables: A review of the literature and proposed theoretical framework to guide future research. Journal of Career Development, 35 , 87-106. https://doi.org/10.1177/0894845308325643

Wright, S.L. \& Perrone. (2010). An examination of the role of attachment and efficacy in life satisfaction. The Counseling Psychologist, 38, 796-823. https://doi.org/10.1177/0011000009359204

Wright S.L., Perrone-McGovern, K. M., Boo, J. N. \& White, A.V. (2014). Influential Factors in Academic and Career Self-Efficacy: Attachment, Supports, and Career Barriers. Journal of Counseling \& Development, 92 , 36-46. https://doi.org/10.1002/j.1556-6676.2014.00128.

Wu, Ben H. (2018). The Role of Career Optimism and Perceived Barriers in College Students' Academic Persistence: A Social Cognitive Career Theory Approach. Dissertations. 1548.

Young R. A \& Collin, A. (2004). Introduction: Constructivism and social constructionism in the career field. Journal of Vocational Behavior, 64(3), 373-388. https://doi.org/10.1016/j.jvb.2003.12.005 


\section{Notes}

Note 1. Generation Chart refers to three generations in the family environment of the client and relates to the expansion of elements as regards the professional activities and the career of those people. The goal is to locate people with which the client has been identified to, and locate others with which to be able to identify him/herself in order to strengthen his/her own possibilities (Wright \& Perrone, 2008).

\section{Copyrights}

Copyright for this article is retained by the author(s), with first publication rights granted to the journal.

This is an open-access article distributed under the terms and conditions of the Creative Commons Attribution license (http://creativecommons.org/licenses/by/3.0/). 